Al-QANTTARA (AQ)

XXVII 2, julio-diciembre de 2006

pp. $417-445$

ISSN 0211-3589

\title{
LA FORMALIZACIÓN DEL PODER EN LAS MONEDAS DE LOS MULŪK DE DENIA (SIGLO V H./XI D.C.) *
}

\author{
FÉLIX RETAMERO
}

Universidad Autónoma de Barcelona

\begin{abstract}
En este artículo se trata la formalización del poder político de las nuevas dinastías (mulūk al-țawà'if) que gobernaron en al-Andalus tras la desaparición del califato omeya. Para ello se ha tenido en cuenta el análisis de las inscripciones que aparecen en las monedas emitidas por estas dinastías, específicamente la de los 'Āmiríes instalados en Denia, que acuñaron primeramente en Elota y treinta años después en la misma Denia y en Mallorca. Tanto las variables inscripciones reconociendo la autoridad de un imām, como los nombres inscritos de miembros de las familias gobernantes o del séquito palatino revelan de manera conspicua esta nueva legalidad, finalmente cuestionada.
\end{abstract}

Palabras clave: Moneda andalusí; Taifas; Denia.
This article examines the formalization of the political power wielded by the new dynasties (mulūk al-țawä'if) ruling in al-Andalus after the collapse of the Umayyad caliphate, as revealed by coin inscriptions. The study is mainly focussed on the issues of the 'Âmiri rulers who settled in Denia, and whose coinage was initially minted in Elota and about thirty years later in Denia and Mallorca. The variable inscriptions recognising the authority of an imām, as well as the appearance of names corresponding to members of the ruling family and the palatine staff, draw conspicuous attention to this new legality, which was finally to be brought into question.

Keywords: Andalusi coins; Taifa states; Denia.

\section{La imāma}

Según Ibn Baškuwāl, Abū 'Abd al-Raḥmān 'Abd Allāh b. 'Ubayd Allāh b. al-Walīd b. Muhammad b. Yūisuf b. 'Abd Allāh b. 'Abd al-'Azīz b. 'Amr b. 'Uțmān b. Muhammad b. Jālid b. 'Uqba b. Abī Mu'ayt b. Abān b. 'Āmir b. Umayya b. 'Abd Šams, conocido por

* Este artículo incluye algunos contenidos de un trabajo en proceso de elaboración sobre las emisiones monetarias andalusíes de Denia, promovido por el museo de esta ciudad. Quiero agradecer a Josep Gisbert, director del Museu de Dénia, su ayuda y su silenciosa paciencia. Estoy igualmente en deuda con M. Barceló y con V. Martínez Enamorado, quienes han tenido la gentileza de revisar el manuscrito. Los errores que este artículo contiene son, sin embargo, responsabilidad exclusiva del autor. 
al-Mu'ayțī, era un hombre piadoso, inteligente, noble y sabio ${ }^{1}$. Pertenecía a una familia omeya instalada en Córdoba y, de acuerdo con Ibn 'Iḍārī, partió hacia Šarq al-Andalus al principio de la fitna, en el año 405/1014 ${ }^{2}$. Aquel mismo año fue proclamado califa en Denia, y su nombre fue invocado en la juțba en la Šarqiyya a partir de ese momento. Parece claro que el imām 'Abd Allāh reconocido en unas monedas acuñadas en la ceca de Alūta (Elota) a nombre de Muŷāhid en los años 405 y 406 era el mismo al-Mu'ayțī, el notable faqīh emparentado con los Banū Umayya y convertido en califa. F. Codera ya propuso esta identificación, si bien tuvo dudas sobre la fecha del 405 y pensó que podría tratarse del $408^{3}$. La impronta del único ejemplar conocido hasta ahora, que formó parte de la colección del conde de Montenegro, ha sido publicada recientemente ${ }^{4}$. Es cierto que el inicio de la unidad (خمس, cinco), incompleta, bien podría ser confundido con el de دُمان (ocho), pero en ese caso habría que pensar que el maestro acuñador omitió la letra alif de la palabra tamān. Aunque no sería, ni mucho menos, un error excepcional, creo que la lectura del 405 es la acertada, y, de hecho, es la comúnmente aceptada.

Las emisiones de Elota empezaron, no obstante, antes de la proclamación de al-Mu'ayțī como califa. Las primeras series de esta ceca, fechadas en los años 402 y 403, incluyen la invocación del imām Hišām. Se trata de las primeras emisiones producidas lejos de Córdoba, en pleno proceso de descomposición del estado califal. Las series de esta ceca, fechadas entre 402 h. y 406 h. (1011-1016 d. C.), presentan bastantes diferencias en la distribución y en el contenido de las leyendas inscritas. Las de los años 402 y 403 reproducen los tipos califales omeyas corrientes. Destaca, en primer lugar, el reconocimiento del imām Hišām, distinguido con el título de al-Mu'ayyad bi-llāh. Por otra parte, estos ejemplares más antiguos de Elota inclu-

${ }^{1}$ Kitāb al-sila, al-Husaynī, 'I. 'A. (ed.), El Cairo, 1994², I, 261-262, n. 592.

2 Al-Bayān al-mugrib, III: Al-Bayān al-mugrib, tome troisième. Histoire de l'Espagne musulmane au XIème siècle. Texte arabe publié pour le première fois d'après un manuscrit de Fès, Colin, G. S. y Lévi-Provençal, É. (eds.), París, 1930, 115-116, y La caída del Califato de Córdoba y los Reyes de Taifas (Al-Bayān al-mugrib). Estudio, traducción y notas, Maíllo, F. (trad.), Salamanca, 1993, 105.

3 Codera, F., "Mochéhid, conquistador de Cerdeña", Centenario della nascita di Michele Amari, Palermo, 1910, II, 115-133, 121, n.1.

${ }_{4}$ Monedas de las dinastías arábigo-españolas. Láminas. Antonio Vives y Escudero, Madrid, 1998 (= Láminas), 89, n. ${ }^{\circ} 819$.

Al-Qanțara (AQ) XXVII 2, julio-diciembre 2006, pp. 417-445 ISSN 0211-3589 
yen una profusión ornamental - círculos, estrellas, gotas o motivos florales- característica de las emisiones marwāníes tardías ${ }^{5}$.

En cambio, las de 405 y 406, más austeras, contienen la invocación al imām 'Abd Allāh, al-Mu'ayṭī, sin título honorífico alguno. En el ejemplar conocido de 405 fueron inscritos, además, los únicos nombres propios no califales de todas las series de Elota: 'Abd al-Raḥmān, en el anverso, y Muŷāhid, en el reverso. No resulta sorprendente la inscripción del nombre de Muŷāhid, el saăhib 'āmirí, en la parte inferior del área del anverso. Precisamente, durante la hegemonía 'āmirí en Córdoba, los nombres propios de los personajes más importantes de la corte fueron inscritos en el reverso, acompañando al nombre y título califales ${ }^{6}$. De acuerdo con esta disposición habitual en las emisiones omeyas, el nombre del anverso, 'Abd al-Raḥmān en este caso, debería de corresponder al de algún personaje de la corte de rango inferior, presumiblemente el encargado de la ceca ${ }^{7}$.

Hay que tener en cuenta, sin embargo, que para 405 el protocolo que fijaba la jerarquía nominativa omeya ya había sido alterado. Algunas series acuñadas en Córdoba en el 400, y entre el 403 y el 407, a nombre de Sulaymān b. Hakam con el título de al-Musta'īn bi-llāh, incluyen la identificación del sucesor previsto en el imamato y el nombre de este presunto sucesor (Muhammad, en este caso), inscrito tanto en el anverso como, en la mayoría de casos, en el reverso de las piezas ${ }^{8}$. Fue justamente Sulaymān al-Musta'īn bi-llāh quien

5 Un estudio exhaustivo de estos motivos ornamentales se puede encontrar en Frochoso, R., Las monedas califales de ceca al-Andalus y Madinat al-Zahrā', Córdoba, 1996.

6 En época de al-Hakam, los nombres de los prefectos de la ceca eran inscritos tanto en el anverso como en el reverso, de manera que F. Codera consideró que en las monedas omeyas era indiferente que un nombre figurara en una u otra cara. Codera, F., Títulos honorificos y nombres propios en las monedas arábigo-españolas, Madrid, 1878, 43 y 85, y 62-3; y Tratado de numismática arábigo-española, Madrid, 1879, VII.

7 Sobre estos personajes, Canto, A., "Los aṣhāab al-sikka de 'Abd al-Raḥmān III, según Ibn Hayyān y el testimonio de las monedas", Cuadernos de Prehistoria y Arqueologia, 13-14 (1986-87), 271-276. Ocasionalmente, sin embargo, aparecían otros nombres que acompañaban a los de la secuencia de prefectos. Tal fue el caso de un Hišām de los años 334 y 335 (945-947), ya advertido por Codera, F., Títulos honoríficos, 55-6; y también Canto, A., "An extraordinary issue of 'Abd al-Raḥmān III", 10th International Congress of Numismatics, Londres, 1986, 401-407.

8 Vives, A., Monedas, n. os 694-696 y 713-717; Pellicer, J., "Suleiman Al-Mostaîn 400-1010/407-1014”, Acta Numismatica, 14 (1985), 143-160, y Sáenz-Díez, J.I., “Ibn Shuhayd y el año 404", I Jarique de Estudios Numismáticos Hispano-Árabes, Zaragoza, 165-168. Así, en 405 h. el nombre del presunto sucesor, Muhammad, fue inscrito en el 
inició la práctica, seguida poco después por los Hammūdíes, de hacer referencia al sucesor previsto en el califato ${ }^{9}$. Estas series anunciarían, así, las frecuentes alusiones a miembros de la dinastía propias de las emisiones taifas, en detrimento de los nombres de funcionarios, tal como había sido la costumbre en el período precedente ${ }^{10}$.

Así pues, la identificación del 'Abd al-Raḥmān de la pieza de Elota de 405 podría hacerse tanto teniendo en cuenta la antigua práctica omeya y 'āmirí de identificar, a pesar de las excepciones, al funcionario encargado de la ceca en el anverso, como la nueva asociación del califa con el sucesor previsto, introducida por Sulaymān al-Musta'īn. Hay que tener presente, sin embargo, que, según recogió Ibn al-Jatīib, Muŷāhid hizo constar el nombre del hijo de al-Mu'ayțī, que se llamaba 'Abd al-Raḥmān, en las monedas y en los estandartes ${ }^{11}$. La noticia

reverso y el de Ibn Šuhayd en el anverso. En $406 \mathrm{~h}$. el nombre que aparece en el anverso es el de Basīl, y en 406 h. y también probablemente en 407 h., el de Ŷahar; Pellicer, J., "Suleiman", 146. La nómina, de todas maneras, no se acaba aquí. Los nombres de Habīb, 'Alī, Ibn Ḥudayr, Ibn Jalaf, Sulaymān, 'Abd al-Malik y Qind (o Qand) se sucedieron en un período de cinco años, entre el $403 \mathrm{~h}$. y el $407 \mathrm{~h}$. A. Canto ha sugerido la posibilidad de que se tratara de autoridades "independientes" que reconocieran al imām Sulaymān; Canto, A., "Hallazgo de monedas califales de Marroquíes Bajos (Jaén)", Arqueología y Territorio Medieval, 4 (1997), 81-101, 83-84. Uno de estos nombres, 'Alī, corresponde a 'Alī b. Hammūd, que mandó acuñar en Ceuta a nombre del imām Sulaymān, como se verá más adelante. A partir de $407 \mathrm{~h}$., las monedas de esta ceca incluyeron la invocación al imām 'Alī; Pellicer, J., "Suleiman", 145; Vives, A., Monedas, n. os 727-734. Sin embargo, D. Wasserstein afirmó en relación con el nombre de Qand que el personaje de la parte inferior del anverso habría sido un "vizier or mint-official"; Wasserstein, D., The Caliphate in the West, Oxford, 1993, 174.

${ }^{9}$ Codera, F., Títulos honorificos, 76; Prieto, A., Los Reyes de Taifas, 106. Esta innovación, de todos modos, no impidió que el primer oficial de la ceca, Ibn Maslama, fuera el mismo que había trabajado con Muhammad al-Mahdī, el efímero califa precedente, ni que se aprovecharan los cuños de anverso del califa depuesto; Prieto, A., Los Reyes de Taifas, 105; Miles, G. C., "The year 400H./1009 A.D. at the Mint of Cordoba", Numisma, 84-9 (1967), 9-25, 18; Pellicer, J., "Muhammad, amīr al-mu'minīn al-Mahdī billāh Sulaymān amīr al-mu'minīn al-Musta 'īn billāh. Un aprovechamiento del cuño de anverso de un dirhem de al-Andalus 400H (1009-1010)", Gaceta Numismática, 132 (1999), 9-11.

${ }^{10}$ Codera, F., Tratado de numismática, p. VIII; Canto, A., "Hallazgo".

11 Una variante del texto, no obstante, dice que "Abd al-Rahmān era el nombre del propio al-Mu'ayțī; Codera, F., "Mochéhid, conquistador de Cerdeña", Centenario della nascita di Michele Amari, II, Palermo, 1910, 115-133, 122. Se trata, sin duda, de un error, ya que el nombre transmitido en las monedas y documentalmente es el de 'Abd Allāh. Más bien, habría que pensar que se habría confundido con su kunya, Abū 'Abd al-Rạ̣mān, según consta en las crónicas. Esta kunya refuerza el hecho de que el nombre 'Abd al-Rahmān inscrito en las monedas de Elota correspondiera, en efecto, al hijo de al-Mu'ayțī, probablemente al primogénito.

Al-Qanțara (AQ) XXVII 2, julio-diciembre 2006, pp. 417-445 ISSN 0211-3589 
de Ibn al-Jatiīb y la acuñación de los nombres del imām y de su hijo en la pieza de 405 hacen pensar que la construcción de la legalidad de los nuevos poderes habría exigido tanto el reconocimiento califal como el anuncio, inscrito en las monedas, de una vigencia prevista con la alusión del sucesor en el imamato. Se habría pretendido, de este modo, manifestar con esta inscripción la construcción de un orden no contingente, el certificado de una conducción duradera, no provisional ni improvisada, de la comunidad, después del intento 'āmirí de irrumpir en la línea de la sucesión omeya y de la ruptura de la fluidez dinástica. De cualquier manera, el ensayo reflejado en la pieza de Elota de 405 no tuvo continuidad. Los dos ejemplares conocidos del 406 tienen inscritos en las áreas el dogma de la unicidad de Dios y el reconocimiento del imām 'Abd Allāh con el título de amīr al-mu'minin, en el anverso y en el reverso, respectivamente. Ninguna alusión a miembros de la jerarquía sultánica ni a las previsiones sucesorias; sólo aparecen inscripciones que estrictamente aluden a la legalidad islámica de la emisión.

A pesar de la pequeñez de la muestra, las series de Elota muestran variaciones destacables que afectan a las soluciones decorativas, a la invocación califal y a la formalización de la jerarquía nominativa del incipiente Estado. De todas maneras, las características más destacables de estas emisiones no son las vacilaciones decorativas o nominales, sino la brevedad del intento de dotar al nuevo poder de emisiones propias y la magra cantidad de piezas producidas. Sólo se conocen siete ejemplares que puedan ser atribuidos a los 'Āmiríes: dos de 402 h., uno de 403 h., dos de 405 h. y dos de 406 h. Además, en estas dos piezas de $406 \mathrm{~h}$. se utilizó el mismo cuño de anverso ${ }^{12}$.

En el estado actual de los conocimientos sobre las primeras series taifas, parece claro que la brevedad temporal y los escasos volúmenes producidos fueron también propios de otros ensayos contemporáneos. Por ejemplo, otro miembro de los Banū 'Āmir, el fatà Jayrān (o Jayrām, tal como aparece en las monedas), emitió monedas en 404/1013-1014 ${ }^{13}$. Su nombre está inscrito en la última línea del re-

\footnotetext{
12 Se trata de las piezas catalogadas por Vives, A., Monedas, n. ${ }^{\text {os }} 820$ y 821 . La primera formó parte de la colección de F. Codera, y la segunda de la de P. Gayangos. Ambas se encuentran actualmente en la American Numismatic Society.

13 Una pieza fue publicada por J. L. Rodríguez Lorente, quien la atribuyó a la ceca de Valencia; Rodríguez, J. L., "Aportación al estudio numismático de los taifas del Califato, los territorios del eslavo eunuco Jayrān”, Al-Qanțara, II (1981), 453-455. T. Ibrāhīm pu-
} 
verso, después de la invocación al imām Hišām. En el anverso puede leerse el nombre de un desconocido 'Abd al-'Azīz. La distribución es idéntica a la del ejemplar de 405 de Elota, si bien, obviamente, este 'Abd al-"Azìz no puede ser el sucesor previsto en el califato, como en el caso de Elota. Por lo visto, esta efímera emisión no fue más allá de $404{ }^{14}$. El Estado fundado por el antiguo funcionario 'āmirí, finalmente instalado en Almería, no fue un productor regular de monedas, a pesar de este ensayo esporádico. La ceca de Almería acuñó de manera fluida a partir del año 430/1038, después de ser ocupada por 'Abd al-'Azīz de Valencia, otro 'Āmirí, nieto de Almanzor.

Valencia fue una ceca muy activa a partir de 427/1035-1036, de acuerdo con el número de piezas conservadas ${ }^{15}$. Se conocen, no obstante, dos piezas anteriores, acuñadas en 407/1016-1017 a nombre de los antiguos encargados de la ceca, Muẓaffar y Mubārak ${ }^{16}$. En ambos

blicó otra acuñada en Valencia con el nombre de Jayrān en el anverso y el de 'Abd al-'Azīz en el reverso; Ibrāhīm, T., "Adiciones a la numismática de los taifas del Šarq al-Andalus", Gaceta Numismática, 103 (1991), 27-36, 28-29. Ambos autores han identificado a este personaje con quien gobernó Valencia desde 412/1021 con el laqab de al-Manșūr. Clément, F., Pouvoir et légitimité en Espagne musulmane à l'époque des taifas ( $V^{e}-X I^{e}$ siècle). L'imam fictif, París-Montreal, 229, ha cuestionado esta identificación. Por lo que respecta a la ceca, D. Wasserstein, The Caliphate, 185, ha sugerido la posibilidad de que se tratara de Úriyyūla (Oriola). Mostrando menos dudas, Wasserstein ha identificado este nombre de ceca en la pieza de 404 h., también de Jayrān, que formó parte de un depósito encontrado en Trujillo (Cáceres), y que fue publicada hace años por J. de $\mathrm{Na}$ vascués, quien la había atribuido a la ceca de Almería; Navascués, J. de, "Tesoro hispano-árabe hallado en Trujillo (Cáceres)", Numario Hispánico, 6 (1957), 5-28. Clément, F., Pouvoir et légitimité, 234, no ha tenido en cuenta las observaciones de D. Wasserstein sobre la identificación de estas cecas.

${ }^{14}$ A pesar de que G. Miles atribuyera equivocadamente a Zuhayr, mostrando dudas en la lectura de la fecha, una pieza de Almería de $406 \mathrm{~h}$. en la que se invocaba al imām 'Abd Allāh; Miles, G. C., Coins of the Spanish Mulūk al-tawā' if, Nueva York, 1954, 44, n. ${ }^{\circ} 160$. A. Ariza y F. Clément han identificado a este 'Abd Allāh con al-Mu'ayțī y han atribuido, con reservas, la emisión a Jayrān; Ariza, A., "Las cecas de taifas bajo dominio eslavo", Gaceta Numismática, 105-106 (1992), 143-162, 148-149; Clément, F., Pouvoir et légitimité, 231. Sin embargo, D. Wasserstein ha cuestionado también la lectura de Miles (en 406 h. Jayrān no reconocía al imām proclamado en Denia, sino a 'Alī b. Hammūd, contra Sulaymān al-Musta'īn; Al-Bayān al-mugrib, III, 116; trad. Maíllo Salgado, F., 106), y ha sugerido, por un lado, que la fecha más verosímil habría sido la de 426 (y entonces, habría que atribuir la pieza a Zuhayr) y, por otro, que la invocación no habría correspondido a 'Abd Allāh al-Mu'ayṭī, sino al nombre común 'abd Allāh, la fórmula adoptada en las monedas cuando no había candidatos aceptables para ejercer el imamato.

15 Doménech, C., "Les encunyacions monetàries a la taifa amirita de València", Gaceta Numismática, 105-106 (1992), 43-64.

16 Vives, A., Monedas, n. ${ }^{\text {os }} 805$ y 806; Prieto, A., Los Reyes de Taifas, n. ${ }^{\text {os }} 138$ y 139.

Al-Qanțara (AQ) XXVII 2, julio-diciembre 2006, pp. 417-445 ISSN 0211-3589 
ejemplares se reconoce al imām 'Alī al-Nāṣir li-dīn Allāh ('Alī b. Hammūd) en el área del reverso. En la última línea, en una de las monedas, aparece el nombre de Mubārak, mientras que el de Muẓaffar está inscrito en la parte inferior del anverso. En el otro ejemplar, el nombre del reverso es el de Muzaffar, y, supuestamente, el nombre ilegible del anverso sería el de Mubārak ${ }^{17}$. Es decir, que estos dos antiguos funcionarios parece que alternaron los nombres respectivos en el espacio reservado en la última línea del reverso al personaje que detentaba el poder (mulk), tal como hemos visto en los casos de Muŷāhid en la pieza de 405, y de Jayrān, en las monedas de 404. Esta alternancia es congruente con la documentada asociación de Mubārak y de Muzaffar en la gestión del Estado, si bien, de acuerdo con Ibn 'Idārī, Mubārak tenía cierta preeminencia ${ }^{18}$.

El otro grupo constructor de un poder estatal reconocible en la producción de piezas de moneda a principios del V/XI fue el de los Banū Tuŷîb, instalados en Zaragoza. Se conocen monedas acuñadas en oro, fechadas entre 415 y 418/1024-1028, a nombre de Yahyà b. Mundir al-Tuŷībī, y en 420, 423 y 428, a nombre de Mundir b. Yahyà ${ }^{19}$. La distribución de las leyendas en las monedas de Yahyà es similar a la de las series comentadas anteriormente. En el reverso, después de la invocación califal (al imām al-Qāsim, de los Banū Ḥammūd, en la de 415 h., y al imām 'abd Allāh en las posteriores), aparece el nombre de Yahyà con el cargo de hââyib inscrito en la primera línea del área del reverso. Esta referencia al oficio principal de la cancillería palatina no es la única diferencia entre las emisiones tempranas tuŷībíes y las que hemos visto anteriormente. En las monedas de Mundir, además de las vacilaciones en el reconocimiento del imamato ('A bd Allāh en 420 h., Hišām en 423 h., y de nuevo 'Abd Allāh en 428 h.), destaca la nueva inclusión del título sultánico Mu'izz al-Dawla. Esta referencia honorífica será común en las emisiones regulares de dírhemes por parte de los Banū Hūd, a partir de 430/1038 y, de hecho, será una de las características destacadas de las acuñaciones de los mulūk andalusíes a partir de esta fecha.

\footnotetext{
17 Vives, A., Monedas, consignó también el nombre de Muẓaffar en el anverso. He tenido la ocasión de leer la pieza, conservada en el Museo Arqueológico Nacional, y he podido comprobar que el nombre es ilegible.

18 Al-Bayān al-mugrib, III, 159; trad. Maíllo Salgado, F., 139.

19 Vives, A., Monedas, n. ${ }^{\text {s }}$ 1133-1141; Prieto, A., Los Reyes de Taifas, n. ${ }^{\text {os }} 221-230$.
} 
Las series 'āmiríes de Elota comparten algunas características tipológicas destacadas con las emisiones de Jayrān de Almería, con las de Muzaffar y Mubārak de Valencia, y con las de Yahyà y Mundir de los Banū Tuŷīb de Zaragoza. En primer lugar, se mantuvo, en general, la distribución de las leyendas de las emisiones omeyas. De manera específica, el nombre del personaje principal del Estado, aparte de las cambiantes alusiones califales, aparece en la última línea del reverso, tal como había sido costumbre cuando los 'Āmiríes manejaban los asuntos de Estado en Córdoba. Por otra parte, la inscripción del nombre del sucesor previsto en las monedas fue una solución excepcional, distinguible tan sólo en la única pieza conocida de 405 acuñada en Elota, con el nombre 'Abd al-Rahmmān, probablemente, hijo del califa al-Mu'ayțī, acuñado en el anverso. De hecho, únicamente los Banū Hammūd hicieron inscribir el título y el nombre del sucesor de manera regular, ya fuera en el anverso o en el reverso, desde 407/10161017 hasta el final de la dinastía. Más adelante, las emisiones de los mulūk incluirán habitualmente el nombre del sucesor previsto, no en el imamato, como en el caso de los Hammūdíes o, de manera efímera, en la emisión de 405 en Elota, sino estrictamente en el gobierno del Estado. En las emisiones 'āmiríes de Denia de 435/1043-1044 en adelante y, en general, en las de los mulūk ya consolidados, la previsión sucesoria fijada en las monedas fue la del sulțān.

Las inscripciones de las monedas y algunas referencias recogidas en los textos árabes permiten seguir el contenido variable del reconocimiento del imamato, una condición que se mantuvo, no obstante, presente en la mayor parte de las emisiones taifas. Las monedas de 402 y 403 emitidas en Elota expresaban el reconocimiento del imām Hišăm al-Mu'ayyad bi-1lāh, el califa Hišām II; las de 405 y 406 incluían el nombre del imām 'Abd Allāh, al-Mu'ayțī 20. A partir de 435/1042, año en que empezaron las emisiones regulares de los 'Āmiríes de Denia, la invocación se hizo nuevamente a nombre del imām Hišām, el denominado «falso» Hišām ${ }^{21}$. Una vez retirado el reconocimiento al califa hammūdí, fue el hââyib Ibn 'Abbād de Sevilla quien primero invocó a este Hišām, supuesto hijo de al-Ḥakam, el mismo

20 Vives, A., Monedas, n. os 819-821; Prieto, A., Los Reyes de Taifas, n. ${ }^{\text {os }}$ 134-137.
21 Según Ibn 'Id̄ārī (Al-Bayān al-mugrib, III, 200 y 244; trad. Maíllo Salgado, F.,
69 y 203, respectivamente), se trataba del espartero Jalaf al-Ḥușrī, que se parecía mucho a Hišām II.

Al-Qanțara (AQ) XXVII 2, julio-diciembre 2006, pp. 417-445 ISSN 0211-3589 
año 435 22. Según Ibn 'Id̄ārī, este año los mulūk de al-Andalus reconocieron a este Hišām habilitado por los 'Abbādíes inicialmente. Entre ellos, Muŷāhid. Esta invocación fue suprimida de la juṭba en 451/1059-60 por el propio al-Mu'taḍid, si bien continuó inscrita en las monedas acuñadas en Sevilla hasta la llegada de al-Mu'tamid en 461/1068. A. Prieto dudó de la veracidad de estas informaciones textuales, ya que la invocación en las monedas perduró hasta el $461{ }^{23}$. De todos modos, en el caso de que, efectivamente, la supresión del nombre de Hišām en la juṭba hubiera tenido lugar diez años antes que en las monedas, se podría pensar que estas dos prerrogativas califales no tenían la misma consideración en el ejercicio del poder. Una vez reconocido que Hišām —o el espartero sustituto- había dejado de existir, su nombre no podía ser mantenido en la plegaria de los viernes, pero sí en las monedas, como fórmula conocida de sumisión a una autoridad legal.

El cambio de invocación a favor del imām 'Abd Allāh tuvo lugar por primera vez en las monedas 'āmiríes en una serie acuñada en $455 / 1063^{24}$. La inscripción de este nombre ha sido considerada por D. Wasserstein como una manera de solucionar la invocación califal al no disponerse de un nombre de candidato adecuado ${ }^{25}$. Más que como un nombre propio, pues, el imām 'abd Allāh aludido en las piezas de 'Alī Iqbāl al-Dawla, hijo de Muŷāhid, entre 455 y el 468, debe de ser considerado, según el mismo Wasserstein, como una titulación, adecuadamente vaga, con la que se resolvía la estricta exigencia canónica del imamato ${ }^{26}$.

Algunas noticias hacen referencia a estos cambios en las invocaciones califales contenidas en las monedas. Una vez retirada la distin-

${ }^{22}$ Vives, A., Monedas, n. ${ }^{\circ}$ 882; Prieto, A., Los Reyes de Taifas, n. ${ }^{\circ} 395$.

23 Al-Bayān al-mugrib, III; trad. Maíllo Salgado, F., 184. Wasserstein, D., The Rise and Fall, 156-7; Vives, A., Monedas, n. ${ }^{\circ}$ 933; Prieto, A., Los Reyes de Taifas, 100, n. ${ }^{\circ} 401$.

${ }^{24}$ La mayor parte de las piezas emitidas durante este año contienen aún el reconocimiento del imām Hišām. El único ejemplar conocido con el nombre 'Abd Allāh fue publicado por Nützel, H., Katalog der orientalischen Münzen, Berlín, 1902, II, 110, n. ${ }^{\circ} 541$.

25 Wasserstein, D., The Caliphate, 109-119. El nombre fue inscrito primeramente en los dinares de los Banū Tuŷīb del año 416/1025 (Prieto, A., Los Reyes de Taifas, n. ${ }^{\circ}$ 222), después de un efímero reconocimiento del imām al-Qāsim; Vives, A., Monedas, 1133; Prieto, A., Los Reyes de Taifas, n. ${ }^{\circ} 221$; Wasserstein, D., The Caliphate, 114-5.

26 The Caliphate, 116. 
ción califal a al-Mu'ayṭī, Muŷāhid apoyó a otro candidato omeya, 'Abd al-Raḥmān al-Murtaḍà, en el año 408/1017-8. No se conoce ningún testimonio numismático de este reconocimiento, por otro lado efímero. Después de las últimas emisiones de Elota, en 406, el Estado 'āmirí aún tardaría unos cuantos años en acuñar piezas de manera regular. Justamente después de este intento infructuoso de reposición omeya, se dice que Muŷāhid hizo pronunciar la juṭba en Valencia, en 409, a su nombre y al de Labīb, el malik de Tortosa. Poco después, los šuyüj de esa ciudad decidieron nombrar amīr a uno de los suyos, 'Abd al-'Azīz b. 'Abd al-Rahmān, titulado al-Manșūr ${ }^{27}$.

Todo esto muestra las dificultades para encontrar a alguien que reuniera las condiciones exigidas por la tradición política islámica y que contara con los apoyos necesarios. Una vez agotadas las posibilidades de restauración omeya (como la representada por la inscripción del imām Hišām en las monedas de Elota, por ejemplo), de reconocimiento de un califa hammūdí, o de habilitación de una persona que encarnara a un califa desaparecido (la promovida por los 'Abbādíes de Sevilla), en al-Andalus no existía ninguna dinastía con un peso suficiente para presentarse como garantía de la unidad de la comunidad y en condiciones de presentar a un imām con una genealogía impecable ${ }^{28}$. No se trataba de un problema estricto de legitimidad, como veremos más adelante.

Tras la sumisión de Denia a los Banū Hūd en 468/1076, no se produjeron nuevas emisiones en esta ceca hasta el año 475/1082, bajo el mandato del hậyib Mundir 'Imād al-Dawla. Las piezas de Mundِir no contienen ninguna referencia califal. En el anverso, bajo la inscripción del dogma de la unicidad de Dios, aparece el nombre del sucesor

27 Al-Bayān al-mugrib, III, 164; trad. Maíllo Salgado, F., 142; Crónica anónima, 42-3. Según F. Clément, los dos jefes 'āmiríes contestaron con esta decisión la legitimidad del califato hammūdí; Clément, F., Pouvoir et légitimité, 228. Considerando estos hechos, no parece que pueda imaginarse que el califato de al-Mu'ayțī se alargara mucho más allá de la fracasada expedición a Cerdeña de 406/1016. R. Chabás, siguiendo al poco fiable J.A. Conde, pensó que el califato de al-Mu'ayțī perduró hasta 420-1/1029-30; Chabás, R., Historia de la ciudad de Denia, Madrid, 1875, 132; Conde, J. A., Historia de la dominación de los árabes en España, Barcelona. Más recientemente, M. de Epalza ha planteado que, por una "acción política cuya complejidad se nos escapa", Muŷāhid pudo haberse reservado durante cierto tiempo "la baza del piadoso califa omeya"; Epalza, M. de, "El origen político del estado de Denia en el siglo XI: el Califa Al-Muaiti y el Rey Muyáhid", Congrès d'Estudis de la Marina Alta, Alicante, 1986, 157-163, 162.

${ }_{28}$ Sobre la secuencia de las soluciones al imamato habilitadas por los mulūk al-tawā'if, véase el artículo de Fierro, M., "The qā $\bar{l} \bar{\imath}$ as ruler", Saber religioso y poder político en el Islam, Madrid, 1994, 39-51.

Al-Qanțara (AQ) XXVII 2, julio-diciembre 2006, pp. 417-445 ISSN 0211-3589 
previsto en la secuencia dinástica (Sulaymān). En el reverso, el nombre de Mundir en la última línea; su cargo (hââyib) en la primera, y en la línea central su título sultánico ('Imād al-Dawla), seguido de la misión profética ${ }^{29}$. Si bien en algunas series monetarias andalusíes anteriores no se había incluido esta invocación, como por ejemplo en las de feluses, la cuestión era que la omisión introducida por los Hūdíes afectaba a unas series cuya nomenclatura, módulo y disposición de las leyendas correspondían a un tipo monetario repetido desde el califato y en el que siempre se había incluido el reconocimiento califal.

Finalmente, el Estado aparecía sin imām. Y, justamente, esta desaparición era manifestada en el objeto principal de la construcción del mulk, la moneda, que era, a la vez, una de las prerrogativas califales. Significativamente, fue una dinastía procedente del tagr al-a 'là, donde habían prosperado poderes políticos que habían reconocido la autoridad omeya de manera intermitente y a menudo negociada desde el siglo VIII hasta el final del califato, la que sancionó en las monedas la transitoria y excepcional certeza, hasta la restauración almorávide, de que el sulțān podía existir, manifiestamente, sin someterse de manera explícita a la dirección califal.

No parece haber dudas sobre el hecho de que la tendencia a omitir el nombre califal a finales del V/XI representó una solución extrema ante el vacío en el imamato provocado por la definitiva descomposición del orden dinástico omeya y por el fracaso del intento hammūdí de construir un entramado de gobierno y de dirección religiosa perdurable y extenso. De todas maneras, la palmaria hegemonía del orden político, visualizada en los procesos de descomposición o fragmentación de los Estados califales del XI, fue aceptada como una condición necesaria pera permitir el cumplimiento de los preceptos canónicos. Éste fue al menos el sentido, por ejemplo, de las teorizaciones de al-Māwardī (m. 1058 d. C.) y de al-Gazālī (m. 1111 d. C.), centradas en formalizar el discernimiento y las relaciones entre jiläfa y mulk. La distinción de ambas categorías y el reconocimiento del predominio en última instancia de la segunda aparecen claramente, por ejemplo, en el postulado de al-Māwardī según el cual había que dispensar del cumplimiento de alguna de las condiciones que debía de acreditar un imām si ello suponía un benefício para el mantenimiento de la vida de

29 Vives, A., Monedas, n. ${ }^{\text {os }} 1326$ y 1327; Prieto, A., Los Reyes de Taifas, n. ${ }^{\circ} 299 \mathrm{a}$; Guichard, P., L'Espagne et la Sicile musulmanes aux XI et XII siècles, Lyón, 1990, 98.

Al-Qanțara (AQ) XXVII 2, julio-diciembre 2006, pp. 417-445 ISSN 0211-3589 
la comunidad. También fue considerado legal que el califa («aquel a quien rinde fidelidad quien tiene la fuerza») fuera designado por el malik, e, incluso, se llegó a negar la necesidad de que aquél fuera de ascendencia qurayší ${ }^{30}$. Pero en ningún caso se formuló la posibilidad de un sultān sin imām. La juṭa y la acuñación de monedas (sikka) continuaban siendo prerrogativas califales. La opción extrema de los Banū Hūd, manifestada en las piezas acuñadas a partir del 474/1081 en Zaragoza y en algunas series de Lérida, y congruentemente inserida en el bagaje propio de la gestión del Estado, no contó con una teorización contemporánea que sancionara la legalidad del ejercicio del poder disociado de la autoridad califal ${ }^{31}$.

Los emires almorávides resolvieron transitoriamente la cuestión reconociendo al califa 'abbāsí (con la inscripción en las monedas del imām 'Abd Allāh), restaurando la ortodoxia mālikí y respetando inicialmente la vigilancia de los fuqaha ${ }^{32}$. Los dinares almorávides reflejaron esta nueva legalidad. Así, tal como se puede observar, por poner sólo un ejemplo, en la pieza acuñada en Denia en el 501 a nombre de 'Alī b. Yūsuf ${ }^{33}$, la misión profética, presente tanto en las emisiones omeyas como en las taifas, fue sustituida por una inscripción coránica en la orla del anverso en la que se condenaba a los heterodoxos y a los no musulmanes. Por otra parte, Yūsuf b. Tāšfīn aparecía con el título sultánico de amir, evitando escrupulosamente el de $a m \bar{i} r$ al-mu'minin, reservado a los califas de Bagdad ${ }^{34}$. Las soluciones canónicas del imamato, sin embargo, no comportaron la constitución de

${ }^{30}$ Al-Aḥkām al-sulțāniyya, Fagnan, E. (trad.), Les status gouvernementaux, Alger, 1915, 34; Clèment, F., Pouvoir et légitimité, 49; Rosenthal, F., El pensamiento político en el islam medieval, Madrid, 1967, 47 y 58; Lambton, A. K. S., State and Government in Medieval Islam, Oxford University Press, 83-129, especialmente. Más recientemente, Crone, P., Medieval Islamic Political Though, Edinburgo, 219-255. Esta última posibilidad fue contestada por el andalusí Ibn Hazm, Turki, A. M., "L'engagement politique d'Ibn Hazm", Théologiens et juristes de l'Espagne musulmane. Aspects polémiques, París, 1982, 71.

31 Se trata de las piezas acuñadas en la ceca de Zaragoza a nombre de al-Mu'taman, Ahmad al-Musta'īn y 'Abd al-Malik, respectivamente, todos ellos con el título de hāâyib; Vives, A., Monedas, n. ${ }^{\text {os }} 1216-1233$; Prieto, A., Los Reyes de Taifas, n. ${ }^{\text {os }} 269-273$. De la ceca de Lérida, los ejemplares acuñados a nombre de Yūsuf al-Muzaffar: Vives, A., Monedas, n. ${ }^{\circ \mathrm{s}}$ 1241, 1242; Prieto, A., Los Reyes de Taifas, n. ${ }^{\circ \mathrm{2}}$ 283, 284. Tanto Vives como Prieto registraron un solo ejemplar por serie.

32 Viguera, M. J., "Las cartas de al-Gazālī y al-Ṭurțūšī al soberano almorávid Yūsuf b. Tāšufiñ", Al-Andalus, XLII, 2 (1977), 341-374; Fierro, M., "The qā $\bar{l} \overline{\text { as }}$ ruler", 104-5.

33 Vives, A., Monedas, n. ${ }^{\circ} 1602$.

${ }^{34}$ Kassis, H., "Notas históricas sobre las monedas de los almorávides", I Jarique de estudios numismáticos hispano-árabes, Zaragoza, 1988, 55-66.

Al-Qanțara (AQ) XXVII 2, julio-diciembre 2006, pp. 417-445 ISSN 0211-3589 
un Estado perdurable. Pronto, una nueva legalidad y un nuevo sulțān, generados inicialmente entre los Mașmūda magrebíes, sustituyeron al efímero Estado almorávide.

Tanto la omisión del imām en las acuñaciones de los Banū Hūd, como los cambios en las invocaciones califales distinguibles en las piezas 'āmiríes de Denia, reflejan la tensa relación entre la expresión religiosa del orden político y las rutinas propias de la gestión de los Estados. Estos cambios en el reconocimiento califal, promovidos por Muŷāhid y por otros mulūk, no parece que deban ser considerados como el resultado de una errática búsqueda de una legitimidad inevitablemente inalcanzable. De hecho, tal como ha afirmado F. Clément, a pesar de que Muŷāhid reconoció al califa al-Mu'ayțī, apoyó en 408 a al-Murtaḍà, e invocó en sus monedas a Hišām en 435, todo ello no cuestionó su reconocida ortodoxia religiosa ${ }^{35}$. De hecho, lo que intentaron los mulūk de al-Andalus fue reproducir la manera conocida de fijar entramados estables de poder. Y esto incluía, desde luego, el reconocimiento de las prerrogativas califales.

En lo concerniente a la producción de moneda, esta prerrogativa no afectaba exclusivamente a la emisión de piezas. El prestigioso faqih Ibn 'Abd al-Barr fue censurado por otros expertos al aprobar el derecho del mulk de decidir la relación entre las unidades monetarias legales y una cantidad o peso dados de piezas ${ }^{36}$. Ésta era una operación fundamental en la gestión de las capturas fiscales y de las acumulaciones de bienes subsiguientes. Dicho de otro modo, ningún Estado podía funcionar sin fijar estas relaciones entre unidades monetarias de cuenta y las materias - granos, animales, gente o piezas de moneda - reflejados en este corpus contable. La censura de los fu$q a h \bar{a}$ ' reticentes afectaba, pues, a la operación esencial y fundadora de cualquier Estado, fuera o no emisor de piezas.

Muŷāhid, pues, optó por unas soluciones similares a las de otros mulūk, cuestionadas por una buena parte de los fuqahä', pero no se salió del guión marcado por una tradición política en la que, ya fuera con un imām «excelente» (afḍa) o con uno que no lo fuera tanto (mafdūl), o incluso escatimando las prerrogativas califales como la

35 Clément, F., Pouvoir et légitimité, 230.

${ }^{36}$ Citado en Soravia, B., "Les 'ulamä' andalous au V $\mathrm{V}^{\mathrm{e}}$ siècle de l'Hégire. Antagonistes ou courtisans des mulūk al-tawà' 'îf', Saber religioso y poder politico en el Islam, Madrid, 1994, 285-30.

Al-Qanțara (AQ) XXVII 2, julio-diciembre 2006, pp. 417-445 ISSN 0211-3589 
sikka, no se formuló ni experimentó una manera alternativa y perdurable de organizar el Estado. Hechas estas consideraciones, no hay lugar para considerar, sin más, a al-Mu'ayțī como una «criatura» de Muŷāhid, como un «pelele», o como un «fantoche» ${ }^{37}$. El sabio y noble faqīh, como lo describiera Ibn Baškuwāl, constituyó, junto al apoyo suscitado por los 'Āmiríes desplazados a Denia, una solución al ejercicio del poder político que admitía pocas variaciones, y todas ellas eventualmente cuestionables.

\section{El mulk ausente; los nuevos mulūk}

En la tradición política omeya andalusí, el mulk constituyó una expresión de la legitimidad del orden político asociado a la dirección califal, puesta de manifiesto, de manera destacada, en las producciones cerámicas estatales en verde y manganeso ${ }^{38}$. Se trataba de una expresión de legalidad vinculada a la dirección unitaria de una comunidad compacta y sometida a una sola autoridad. De hecho, la extinción de la dinastía omeya en al-Andalus no sólo supuso la necesaria restauración del imamato, de acuerdo con la tradición política vigente, sino también la nueva construcción de la soberanía política, descompuesta. Y, como se sabe, esta construcción nueva del gobierno de la comunidad se llevó a cabo de manera fragmentada, y así el mulk, aquella manifestación de la legalidad política omeya inscrita en las vajillas de corte, desapareció como expresión reconocida del gobierno singular de la comunidad. La denominación mulūk al-țawā'if, inicialmente utilizada por los fuqaha ' de Siŷilmāsa para referirse a las nuevas construcciones políticas magrebíes y andalusíes del XI, muestra la pluralidad de soberanías construidas en ausencia de aquel gobierno presentado como único y como expresión política legítima del imamato. El complemento de este nombre plural, al-tawä'if, expresaba justamente la partición de esta soberanía singular y anterior ${ }^{39}$. Tras la

\footnotetext{
37 Como han hecho, respectivamente, Scales, P., The Fall of the Caliphate of Cordoba. Berbers and Andalusis in Conflict, Leiden-Nueva York-Colonia, 1994, 97; Wasserstein, D., The Caliphate in the West, 127; y Clément, F., Pouvoir et légitimité, 230.

38 Barceló, M., "Al-mulk, el verde y el blanco. La vajilla califal omeya de Madīnat al-Zahrā’”, El sol que salió por Occidente, Jaén, 1997, 187-194.

39 Barceló, M., "De mulk a mulūk. Esperando a los al-murābițūn", De Toledo a Huesca. Sociedades medievales en transición a finales del siglo XI (1080-1100), Laliena, C. y Utrilla, J. F. (eds.), Zaragoza, 1998, 61-65.
} 
descomposición del Estado omeya, pues, el mulk debió de continuar siendo un referente de legalidad política durante cierto tiempo, hasta que la definitiva consolidación de las nuevas dinastías acabara siendo sancionada con la adopción de un término de la misma raíz, pero que contenía un manifiesto cuestionamiento de la legalidad hasta entonces reconocida. La tensa relación entre la dirección religiosa y el gobierno también se hizo bien evidente en el califato 'abbāsī ya en el siglo $\mathrm{X}$, con usurpaciones y pérdidas de atribuciones ejecutivas de los califas que suscitaron la necesidad de codificar una legalidad que regulara las relaciones entre el imamato y el poder temporal, cuya mera existencia, sin más, acabó siendo considerada por muchos juristas, entre los que destacó al-Māwardī, como una condición necesaria para el mantenimiento del orden social, y pues, de la vida religiosa de la comunidad ${ }^{40}$. De manera aún más evidente, en al-Andalus, en el XI, el califato había dejado de ser, también, una expresión de autoridad política, y aquel mulk, ya irremisiblemente ausente, fue sustituido por unos órdenes nuevos en los que la dimensión estrictamente gubernativa, el poder temporal, acabaría conformando en buena medida la expresión de una legalidad finalmente transitoria. De manera destacada, las monedas de los mulūk andalusíes permiten identificar las formalizaciones de esta legalidad.

Por lo visto, y descontado el presunto intento de ejercer el poder por su cuenta narrado por Ibn Jaldūn, las condiciones canónicas de al-Mu'ayțī no fueron suficientes para dirigir un Estado y fijar un orden dinástico en el que se regulara la transmisión del poder. Ni el apoyo obtenido, ni las cualidades acreditadas bastaron para hacerlo partícipe destacado en la construcción de la nueva dinastía. Muȳāhid, de los Banū 'Āmir, quien sin duda sabía más de todo eso, ya estaba en Denia cuando llegó al-Mu'ayțī. Fue precisamente Muŷāhid y «los que estaban con él» los que promovieron la proclamación del faqīh como califa. Antes de la llegada de los 'Āmiríes, Denia había estado bajo la regencia del șăhib Aflah o al-Fath ibn Aflah desde una fecha incierta, pero en todo caso posterior a 401/1010-11. No está claro en qué circunstancias tuvo lugar la sucesión o la transmisión de autoridad entre los dos aṣhāa b. Al-'Uḍrī e Ibn al-Jațīb recogieron la noticia de la muerte de un Aflah en Almería a manos de Jayrān cinco meses antes de la proclamación de al-Mu'ayțī. Es probable que se hubiera

${ }^{40}$ Lambton, A. K. S., State and Government, 73, 92 y pas.

Al-Qanțara (AQ) XXVII 2, julio-diciembre 2006, pp. 417-445 ISSN 0211-3589 
tratado del mismo șạhib de Denia. Así lo hace pensar el nombre y la coincidencia cronológica con la llegada de Muŷāhid y su séquito a esta ciudad ${ }^{41}$.

Muŷāhid al-'Āmirī había recibido una educación palatina en Córdoba, había formado parte del cuerpo de altos funcionarios de la corte (fityān) y había sido gobernador (wālì) nombrado por Ibn Abī 'Āmir al-Mansūur poco antes de la descomposición del Estado califal ${ }^{42}$. Además de contar con formación y experiencia como hombre de Estado, y tal vez por ello, Muŷāhid se desplazaba con un grupo capaz de suscitar adhesiones y de forzar sumisiones. Hay diferentes versiones sobre el itinerario seguido por Muŷāhid y sus seguidores ${ }^{43}$. Si bien aparecen en la documentación escrita como un poder reconocido en Denia en 405, poco antes de la promoción califal de al-Mu'ayṭì, algunas informaciones textuales dan a entender que salieron de Córdoba unos cuantos años antes ${ }^{44}$. Ibn Jaldūn recogió la noticia de la estancia

41 Wasserstein, D., The Caliphate, 125-6.

${ }^{42}$ Era un saqlabi, un miembro del séquito cortesano, comprado o capturado, y preparado en los asuntos domésticos, administrativos o militares del estado. Los fityān envolvían a los diferentes cuerpos del aparato estatal omeya en la escenografía ceremonial exhibida en las grandes ocasiones. V. Barceló, M., "El califa patente: el ceremonial omeya de Córdoba o la escenificación del poder", El sol que salió por occidente, 137-162. Sobre los saqāliba, Scales, P. C., The Fall of the Caliphate, 133-135, y la reciente obra de Meouak, M., Saqāliba, eunuques et esclaves à la conquête du pouvoir. Géographie et histoire des élites politiques "marginales" dans l'Espagne umayyade, Helsinki, 2004. Asimismo, sobre el saqlabī más célebre, Ŷa'far ibn 'Abd al-Rahmān, Martínez Enamorado, V., Un hombre para el Califato. De nuevo sobre Ŷa far el Eslavo a partir de un cimacio con grifos, Málaga, 2006.

43 Según Ibn 'Iḍārī, fue nombrado gobernador de Denia por Ibn Abī 'Āmir y al inicio de la fitna era gobernador de las tres islas orientales, desde donde sometió Denia (La caída del Califato, trad. Maíllo, F., 135). También al-Maqqarī, The History of the Mohammedan dynasties in Spain; extracted from the Nafhu-t-tib by al-Maqqari, Gayangos, P. de (trad.), 1843 (reimp., 1964 por Johnson Reprint Corporation), II, 257. Según Ibn Jaldūn, Muŷāhid dejó Córdoba en 400/1010 y se dirigió a Tortosa. Estas informaciones han sido recogidas y comentadas por Wasserstein, D. J., The Caliphate, 121-122. Sobre la vida de Muŷāhid, aparte de la entrada de Lévi-Provençal, É., EI, Sarnelli, C., "La vita intelletuale a Denia alla corte di Mujāhid al-'Āmirī”, Annali dell'Istituto Orientale di Napoli, XIV (1964), 597-622. No he podido consultar el libro de la misma autora Mujāhid al- 'Āmirī wa-bnu-h "Iqbāl al-Dawla", El Cairo, 1961. Sobre la participación de Muŷāhid en los intentos de restauración omeya en Córdoba durante la fitna, Scales, P. C., The Fall of the Caliphate, 132 y ss.

${ }^{44}$ Según Ibn Jaldūn, la salida habría tenido lugar en 400/1010 La fecha sería congruente con la información proporcionada por Ibn 'Iḍārī, según la cual Muŷāhid, que murió en 436/1044-45, gobernó Denia durante treinta y seis años y con la información del mismo autor sobre una expulsión de 'Āmiríes de Córdoba que tuvo lugar en 399/1009; al-Bayān al-mugrib, III, 76; Maíllo Salgado, F. (trad.), 76. Ha recogido estas informacio- 
de los 'Āmiríes de Muŷāhid en Valencia antes de su instalación en Denia. Si las monedas de Elota fechadas en 402 y 403 fueron acuñadas por orden de Muŷāhid, como las emitidas en esta ceca con su nombre inscrito (405) o sin él (406), entonces habría que pensar que el grupo itinerante de 'Āmiríes permaneció un tiempo en este lugar, antes de llegar a Denia, y que las piezas de 405 y 406 de esta ceca fueron acuñadas cuando el grupo que mandaba Muŷāhid ya estaba en Denia gobernando y había proclamado un califa.

No se sabe quiénes ni cuántos formaron parte de este grupo itinerante. No fue, por otra parte, el único que, tras salir de Córdoba, acabó fundando o engrosando un nuevo Estado. Ibn 'Idāāī contó cómo tras el infructuoso intento de asegurar la continuidad del califato omeya en la persona de 'Abd al-Raḥmān al-Murtadà en 409/1018-19, los Marwāníes se dispersaron por al-Andalus ${ }^{45}$. Cuando los antiguos encargados de la ceca, Mubārak y Muzaffar, se convirtieron en gobernantes hacia 401, grupos de mawāli, de șaqāliba, de francos (ifrānŷ), de vascos (baškunaš) y gentes fugitivas y desterradas se instalaron en Valencia y alrededores. Entre éstos, había gente de Córdoba. De acuerdo con Ibn Hayyān, otros fueron a parar a Zaragoza, donde gobernaba el hââyib Mundir b. Yahyà, de los Banū Tuŷīb, fundador a la postre de otra dinastía. La noticia de Ibn 'Idāāī sobre la dispersión de los Marwāníes incluye una observación sobre la pérdida de notorie-

nes Wasserstein, D. J., The Caliphate, 122. También Scales, P. C., The Fall of the Caliphate, 136. En este caso, sin embargo, habría que pensar que Muŷăhid, o bien fue directamente a Denia, o bien ya estaba allí en $400 \mathrm{~h}$. Tampoco se puede descartar que la salida de Córdoba hubiera tenido lugar cuando se proclamó califa Sulaymān al-Musta'īn, en 403/1013. El mismo Ibn 'Idārī sitúa la huida de los 'Āmiríes hacia el Šarq y la sumisión de Valencia, Játiva, Denia y otros lugares en ese año. También menciona una huida de la gente "hacia las costas y los campos" en el año 401h.; al-Bayān al-Mugrib, III, 113-4; trad. Maíllo Salgado, F., 104-5. Según Wasserstein, D., The Caliphate, 125-7, la presencia de Muŷāhid en Denia no puede datarse antes de 405/finales de 1014.

45 Al-Bayān al-mugrib, III, 126-127; trad. Maíllo Salgado, F., 114. Justamente, quien acabó con al-Murtaḍà, Zāwī, con un grupo de los Banū Zīrī, se fue poco después a Ifrìqi$y a$, advirtiendo a los suyos que eran poca gente, y por lo tanto, vulnerables. Al-Bayān al-mugrib, III, 128; trad. Maíllo Salgado, F., 115. Antes, los šuyūj de los Banū Zīrī habían decidido abandonar al-Andalus e instalarse en el Magreb. Cuando pasaron por Ilbīra, se dice que los habitantes les pidieron protección. Después de llegar a un acuerdo, los Banū Zīrī interrumpieron su marcha, se quedaron y fundaron una dinastía, de acuerdo con el relato de 'Abd Allāh ibn Buluggīn, el último malik de los Banū Zīrī; El siglo XI en primera persona. Las "Memorias" de 'Abd Allāh, último rey zìri de Granada, destronado por los almorávides (1090), trad. Lévi-Provençal, É. y García Gómez, E., Madrid, 1980, 84-5.

Al-Qanțara (AQ) XXVII 2, julio-diciembre 2006, pp. 417-445 ISSN 0211-3589 
dad de éstos y sobre su confusión con la gente corriente. En el mismo al-Bayān al-mugrib se dice que los habitantes de Córdoba llegados a Valencia, además de construir residencias y palacios, se hicieron cargo de huertos e hicieron correr el agua por ellos ${ }^{46}$.

La narración que del desplazamiento de los Banū Irniyyān hizo el mismo Ibn 'Id̄ārī permite hacerse una idea del aspecto y de las dimensiones de alguno de estos grupos migrantes, capaces de asegurar su supervivencia una vez disuelta su relación con el poder, de crear y de gestionar espacios agrarios, y, eventualmente, de generar sumisiones y adhesiones que pudieran acabar fijando un orden dinástico. Según Ibn Jaldūn, los Zanāta Banū Irniyyān habían sido una de las facciones más temibles del ejército califal en tiempos de al-Manșūr ${ }^{47}$. Iniciada la fitna, constituyeron una dinastía en Arcos, en Jerez, en Algeciras y en Calsena. En 446/1054-55, se vieron obligados a abandonar el hiṣn de Arcos y a entregar todo lo almacenado en él a los Banū Zīrī a cambio de un nuevo lugar donde instalarse. El grupo que otrora encarnara una dinastía que había abarcado tres generaciones partió de Arcos hacia un lugar desconocido con sus rebaños y con sus bienes cargados en quinientas mulas. De nada sirvió el acuerdo, pues la caballería de al-Mu'taḍid b. 'Abbād atacó a los Irniyyān mientras se desplazaban y los exterminó ${ }^{48}$.

Cuesta imaginar que el desplazamiento de los 'Āmiríes de Muŷāhid hubiera tenido un aspecto muy diferente al descrito por Ibn 'I dִārī en el caso de los Irniyyān: recuas trajinando; gente en movimiento capaz de organizar la supervivencia, tanto durante el desplazamiento (un aspecto técnico sobre el que a penas se tienen conocimientos), como, llegado el caso, en el lugar donde se produjera el establecimiento del grupo. No hay duda, de todas maneras, de que la capacidad de generar poder, finalmente fijado dinásticamente, fue la dimensión más destacada de la actividad de Muŷāhid y los suyos en la documentación escrita. Y ciertamente, los conocimientos técnicos de Muŷāhid y de buena parte de sus acompañantes sobre los asuntos del gobierno tuvieron que ver con el éxito de estos 'Āmiríes, tanto en

\footnotetext{
46 Al-Bayān al-mugrib, III, 160-1; trad. Maíllo Salgado, F., 139-40; Turk, A., "El Reino de Zaragoza en el siglo XI de Cristo (V de la Hégira)", Revista del Instituto Egipcio de Estudios Islámicos en Madrid, XVII, 7-122, 48.

47 Al-Bayān al-Mugrib, III, 190; trad. Maíllo Salgado, F., 280-2.

48 Al-Bayān al-Mugrib, III, 243 y 272-3; trad. Maíllo Salgado, F., 202 y 226; Ibn al-Jatīib, A'māl, 238-9; Crónica anónima, 28-9, n. 29.
}

Al-Qanțara (AQ) XXVII 2, julio-diciembre 2006, pp. 417-445 ISSN 0211-3589 
el momento del reconocimiento inicial de su autoridad, primero previsiblemente en Elota y después en Denia, como en la consolidación dinástica ulterior. Pero los conocimientos sobre los asuntos de Estado, y de manera destacada sobre la organización de rutinas fiscales, no bastaron para asegurar el éxito de la incipiente dinastía. El impulso fundador de un orden estable de poder exigía la movilización de gente, la capacidad de aglutinar, mediante la adhesión o la sumisión forzada, contingentes de población que sustentaran el poder naciente bajo la autoridad del ra'īs Muyāhid: aquéllos aludidos vagamente por Ibn 'Id̄ārī como «muchos partidarios» ${ }^{49}$. En el siglo V/XI, el poder, como los campesinos, se desplazaba en grupo. Poco tiempo después de llegar a Denia, cuando la nueva dinastía ya había desplegado los procedimientos propios de un poder debidamente formalizado - en la producción de moneda y en la investidura califal, de manera destacada- aún mostrará esta movilidad cuando se traslade a las Islas orientales y, después, a Cerdeña. Esta vez lo hará, no a lomos de bestia, sino en barcas.

Así pues, cuando en 405 al-Mu'āyṭi fue nombrado califa, Muŷāhid ya mandaba. No conozco ninguna mención al respecto, pero el reconocimiento del poder 'āmirí en Denia y en los distritos sometidos debió de exigir la celebración de la bay 'a, bien documentada en otros casos ${ }^{50}$. Con esta ceremonia se escenificaba el compromiso de sumisión de la comunidad y la aceptación de las condiciones que regularían las relaciones entre el poder y los súbditos ${ }^{51}$. Las informaciones sobre la constitución de los mulūk andalusíes contemporáneos incluyen algunas referencias de estas celebraciones, y no hay motivos para pensar que en el caso de Muŷāhid el procedimiento hubiera sido diferente. Así sucedió después en la misma Denia, cuando al-Muqtadir acabó en 468/ 1075-6 con la dinastía iniciada por Muŷāhid. Entonces, de acuerdo con el Bayān, recibió la bay'a tanto de la gente principal (jāsssa) como de la común ('āmma) de la medina ${ }^{52}$.

Pero la formalización del poder político estatal exigía, aún a principios del V/XI, el reconocimiento de un califa a partir del cual, por

49 Al-Bayān al-mugrib, III, 116; trad. Maíllo Salgado, F., 105.

50 Por ejemplo, las noticias sobre la bay'a recibida por 'Abd al-'Azīz al-Mansūr en Valencia y la de Muhammad b. 'Īsà; Crónica anónima, 43 y 34.

51 Rosenthal, E. İ. J., El pensamiento político, 49.

52 Al-Bayān al-mugrib, III, 228; trad. Maíllo Salgado, F., 191. 
delegación, fueran ordenados los asuntos de la comunidad. La organización del sulțān contenía la imāma. Por ello, el nombramiento de al-Mu'ayțī y la invocación de su nombre en la juṭba, en los estandartes y en las monedas, no eran sólo meros formalismos rutinarios. El reconocimiento de la autoridad de un imām era una condición principal de una tradición política en la que precisamente en aquellos momentos se empezaba a plantear de manera explícita la tensa convivencia entre la dirección de la comunidad de los creyentes y la gestión de los Estados ${ }^{53}$. En 405 no existía aún, ni una experiencia estable, ni una codificación del mulk independiente de la jiläfa.

Si bien sus nombres aparecían de manera sistemática en algunas series marwāníes, los prefectos de la ceca no tenían un rango destacado en la jerarquía palatina, de acuerdo con lo que se sabe del ceremonial omeya ${ }^{54}$. A partir de Almanzor, los personajes ocupados en la gestión de los asuntos estatales cuyos nombres eran inscritos en las monedas ocupaban rangos superiores al de los encargados de la ceca. Desde entonces y hasta el final del califato omeya, los nombres de los jefes 'Āmiríes, el del mismo Almanzor, el de su hijo 'Abd al-Malik y el de su sobrino 'Abd al-'Azīz después, fueron sistemáticamente inscritos en los reversos de las piezas, debajo del título y nombre del califa. No obstante, en el anverso se mantuvieron los nombres de algunos personajes secundarios. A partir de 430, aproximadamente, los mulūk andalusíes acabaron consolidando la solución adelantada por los 'Āmiríes durante el califato consistente en formalizar en el protocolo nominal de las monedas el orden sucesorio en el gobierno.

Las primeras series 'āmiríes acuñadas en Denia están fechadas en 430 y 432, según la lectura que hiciera A. Prieto Vives ${ }^{55}$. Resulta destacable el hecho de que no aparezca en las emisiones de estos años el nombre de Muŷāhid, sino el de Hasan, con toda probabilidad su hijo, y el de otros personajes no identificados, en el anverso de algunas series. Prácticamente todo lo que se sabe sobre estas emisiones iniciales de Denia lo escribió A. Prieto Vives en su noticia de un hallazgo pro-

\footnotetext{
53 Rosenthal, E. I. J., El pensamiento político, 45, escribió sobre esta cuestión, planteada por él como una "adecuación" de la realidad política a los preceptos del Corán y de la sunna, Más recientemente, Crone, P., Medieval Islamic Political Thought.

${ }^{54}$ Canto, A., "Los aṣhāb al-sikka"; Barceló, M., "El califa patente".

55 Prieto, A., "Hallazgo de monedas hispano-musulmanas", Revista de Archivos, Bibliotecas y Museos XXXI (1914), 362-367.
}

Al-Qanțara (AQ) XXVII 2, julio-diciembre 2006, pp. 417-445 ISSN 0211-3589 
cedente de la provincia de Jaén ${ }^{56}$. Este depósito estaba formado por piezas de módulo pequeño, como el de las fatimíes, de las cecas de Valencia, Denia, Murcia, Toledo, Alpuente y Tortosa, y todas ellas eran anteriores al 435/1043-1044. A. Prieto describió nueve ejemplares, correspondientes a otros tantos tipos. Por primera vez, se disponía de algunas monedas de estas series con la fecha legible (uno de $430 \mathrm{~h}$. con el nombre 'Abd Allāh en el anverso, y dos de $432 \mathrm{~h}$. con el de Ŷahwar), y con el nombre de la ceca claramente identificado ${ }^{57}$. Este material, que confirmaba la implicación del hijo pequeño de Muŷāhid en la emisión de monedas, llevó a A. Prieto a aventurar «un reinado de Hasán en vida de su padre», del que no parece haber noticias. Por otra parte, R. Chabás escribió que estas acuñaciones habrían sido el resultado de una rebelión de Hasan contra su padre. Además de no haberse conservado ninguna referencia textual que confirme esta posibilidad, el hecho de que el nombre de Hasan vuelva a aparecer en las emisiones posteriores de Muŷāhid, a partir de 435, hace pensar que, aun en el caso de haberse producido esta rebelión, debió de haber mediado algún acuerdo para asociar a Ḥasan a la dirección del Estado, tal como propuso M. Barceló ${ }^{58}$.

56 Ibidem. Anteriormente, F. Codera había descrito tres tipos de estas series. En uno de ellos aparecía parcialmente inscrito el laqab al-dawla en la parte superior del reverso, y en otro, el nombre de un desconocido Ahmad en la última línea del reverso. En los tres tipos era visible el nombre de Hasan, siempre en el reverso. F. Caballero, siguiendo a Codera, precisó las colecciones en las que se encontraban los cuatro ejemplares conocidos en aquel momento, correspondientes a los tres tipos descritos por Codera. De la Rada registró el único ejemplar conservado entonces en el Museo Arqueológico Nacional - tal como había notificado F. Caballero unos años antes-, y expresó algunas dudas sobre el origen deniense de la pieza. A. Vives describió un tipo nuevo en el que aparecía el nombre 'Abd Allāh en el anverso. Codera, F., Tratado, 74, n.1; Caballero Infante, F., Estudio sobre las monedas árabes de Denia, Denia, 1889, 9-11; Vives, A., Monedas, XVII y n. ${ }^{\text {os }}$ 1323-1325.

57 Sorprende, no obstante, que en el libro de 1926, Prieto, A., Los Reyes de Taifas, 36 y 122 , hiciera tan sólo referencia al año 432, única fecha legible que aparecía "en algún ejemplar".

58 Ibidem, 36; Chabás, R., "Mochéhid, hijo de Yúsuf, y Alí, hijo de Mochéhid”, Homenaje a D. F. Codera, Zaragoza, 411-434; Barceló, M., "Assaig d'un corpus numismàtic de la taifa 'āmirida de Dānya-Mayūrqa (436-468)", IV Coloquio Hispano-Tunecino, Madrid, 43-57. Rubiera, M. J., La taifa de Denia, Alicante, 1985, 94-5, ha sugerido que Hasan habría acuñado estas piezas tras su salida de Denia en alguno de los lugares donde se refugió (Valencia o Sevilla). Es decir, que habría falsificado tanto el nombre como las fechas de las emisiones. Ariza, A., "Las cecas de taifas", 153, ha cuestionado esta posibilidad alegando que la falsificación de las fechas no habría tenido sentido. De hecho, la interpretación de Rubiera es insostenible, ya que, además de las objeciones presentadas por

Al-Qanțara (AQ) XXVII 2, julio-diciembre 2006, pp. 417-445 ISSN 0211-3589 
La presencia solitaria de Hasan en las monedas anteriores a $435 \mathrm{~h}$. puede ser explicada de manera menos forzada, sin tener que recurrir a las rebeliones ni a las falsificaciones referidas. Hasan, designado en primer lugar como sucesor de Muŷāhid ${ }^{59}$, bien pudo haber sido asociado al gobierno, de manera que la emisión de piezas a su nombre hubiera formado parte de las atribuciones derivadas de esta asociación. Tal como se verá más adelante, la organización de las dinastías taifas comportó a menudo la plasmación numismática de esta vinculación.

Las emisiones 'āmiríes de las cecas de Denia y Mallorca de 435 en adelante también reflejan esta asociación en la gestión del Estado, en este caso, con el nombre de Muŷāhid en el lugar habitualmente reservado a los personajes principales de la dinastía, en la última línea del reverso, debajo del imām Hišām, precisamente en el mismo lugar donde eran inscritos con frecuencia los nombres de los 'Āmiríes al final del período omeya. En el anverso, junto al dogma de la unicidad de Dios, aparecen los nombres de 'Alī y de Hasan. Los dos fueron hijos de Muŷāhid, pero de madres diferentes. El primero, cuyo nombre figura en la primera línea del anverso, fue capturado durante la expedición de Cerdeña de 406/1015-1016 y recuperado mediante un rescate años después. El segundo, identificado con el laqab Sa'd al-Dawla, fue el designado en primera instancia como sucesor de Muŷāhid, según Ibn 'Iḍārī ${ }^{60}$. De hecho, su nombre está inscrito en el lugar que ocupa habitualmente el sucesor previsto, en la última línea del anverso. Podría pensarse, pues, que la asociación de los dos hermanos en la sucesión del gobierno no habría impedido que uno de ellos, Hasan en este caso, hubiera tenido un rango más elevado, dada la posición de los nombres en las monedas de 435 y 436 . No obstante, esta observación numismática, si bien es congruente con la noticia del nombramiento inicial de Hasan, no lo es tanto con el hecho de que Muŷāhid acabara transfiriendo el poder a 'Alī, teniendo en cuenta, además, que este traspaso de las atribuciones gubernativas se habría hecho en detrimento de Hasan. De cualquier modo, parece claro que la previsión

Ariza, obliga a imaginar a Hasan produciendo moneda (fijando las unidades de cuenta y las especies de curso legal; habilitando redes de distribución y de recolección de las piezas, etc.) en un espacio monetario gestionado por otros poderes que, obviamente, tenían el monopolio de la creación de moneda.

59 Al-Bayān al-mugrib, III, 157-8; trad. Maíllo Salgado, F., 137.

${ }^{60}$ Al-Bayān al-mugrib, III, 157; trad. Maíllo Salgado, F., 137. 
sucesoria - $\mathrm{O}$, al menos, una de ellas — contemplaba la asociación de los dos hermanos de padre en la gestión del Estado, aunque las vacilaciones en la atribución del lugar preeminente en esta sucesión hubieran llevado a Hasan a intentar el asesinato de 'Alī en un callejón de Denia cuando éste volvía de mirar el mar ${ }^{61}$.

La asociación de dos personas en la dirección del Estado con autoridad desigual no fue una solución inédita en al-Andalus. Poco antes, como ya se ha comentado páginas atrás, los antiguos funcionarios Muzaffar y Mubārak habían gobernado de esta manera la taifa de Valencia. Tampoco fue nada nuevo que los nombres de dos hermanos implicados en los asuntos de gobierno aparecieran juntos en el anverso de las monedas, como por ejemplo en las series de al-Qāsim ibn Hammūd, en las que fueron inscritos los nombres del sucesor previsto, Yahyà, y del hermano, Idrīs. De la misma manera, Mundir de los Banū Tuŷīb nombró como sucesores a sus hijos Yahyà y al-Hakam, este último encargado del mando del ejército ${ }^{62}$. Es de suponer que esta asociación en el gobierno de los dos hermanos paternos habría obligado a pactar las delicadas diferencias de rango en el mando y en el protocolo.

En el caso de Ḥasan y de 'Alī, además, las noticias textuales informan de que el marido de la hermana uterina de Hasan, al-Mu'tadid b. 'Abbād de Sevilla, intervino a favor de su cuñado cuando se produjo la ruptura de la tensa y efímera coparticipación ${ }^{63}$. Éste no fue el único vínculo familiar establecido por los 'Āmīríes de Denia con otros grupos dinásticos. Otra hermana por parte de madre fue a parar a la corte de Valencia, precisamente el lugar al que se dirigió Hasan en primera instancia después del atentado frustrado contra su hermano ${ }^{64}$. Por

61 Ibidem. Una carta de 'Alī ibn Muŷāhid reproducida por Ibn Basșām y traducida por Rubiera, M. J., La taifa de Denia, 93, ofrece una narración diferente de los acontecimientos. Según este texto, 'Alī yacía cubierto por una mosquitera cuando fue atacado.

62 Wasserstein, D., The Caliphate, 77-8; Viguera, M. J., "La corte tuŷībí de Zaragoza en el dīwān de Ibn Darrāŷy", Actas del IV Coloquio Hispano-Tunecino, Madrid, 1983, 243-251, 247.

63 Se dice en la carta de 'Alī reproducida por Ibn Basșām; Rubiera, M. J., La taifa de Denia, 92.

64 Al-Bayān al-mugrib, III, 157; trad. Maíllo Salgado, F., 137. La transferencia de una hija al grupo 'āmirí de Valencia tuvo lugar en el contexto de los enfrentamientos entre Muŷāhid y 'Abd al-'Azīz, nieto de Almanzor, en 431/1039-1040, en cuya resolución intervino Sulaymān b. Hūd de Zaragoza. La consecución del acuerdo comportó que una mujer de los Banū Hūd se casara con 'Alī b. Muŷāhid.

Al-Qanțara (AQ) XXVII 2, julio-diciembre 2006, pp. 417-445 ISSN 0211-3589 
otra parte, 'Alī ibn Muŷāhid se casó con una mujer de los Hūdíes de Zaragoza, los mismos que acabarían con la dinastía 'āmirí de Denia en 468/1076. También parece ser que una hija del cuñado de 'Alī, Muhammad al-Mu'tașim bi-llāh de Almería, residió en Denia ${ }^{65}$. Estas transferencias de mujeres entre diferentes grupos dinásticos permitían engrandecer los linajes y sancionaban la consecución de acuerdos diplomáticos ${ }^{66}$. Tales transferencias, con las condiciones pactadas entre los grupos implicados, propiciaron sin duda la intervención en las transmisiones dinásticas. Puede pensarse, pues, que la oposición de Hasan a la hegemonía de su hermano mayor, a pesar de la asociación prevista inicialmente, tuvo lugar en un contexto en el que las solidaridades de diferentes grupos emparentados pesaban de manera decisiva en la organización de los distintos gobiernos.

Tras el extrañamiento de Ḥasan, 'Alī b. Muŷāhid consolidó su hegemonía solitaria en la dirección del Estado. Las inscripciones en las monedas reflejan esta estabilización hasta el final forzado de la dinastía, producido en 468/1076. A partir de 437/1045-1046, 'Alī hizo acuñar el título sultánico Iqbāl al-Dawla en el reverso de las piezas, en la misma cara en la que fue inscrita la invocación califal al imām Hišām hasta el año 457/1065. En las monedas de este año y en las de 467 y 468, se reconoció al imām 'abd Allāh. En el anverso figuraba el nombre de 'Alī y el del sucesor previsto en el mando del Estado, su hijo Muhammad ${ }^{67}$.

A partir de 443/1051-1052, el ism de Iqbāl al-Dawla fue sustituido por el título sultánico del sucesor, Mu'izz al-Dawla. Algunas noticias sugieren que la fijación de la transmisión del poder comportaba la

${ }^{65}$ Chabás, R., "Mochéhid", 425.

${ }^{66}$ Así, se dice que al-Mu'tadid ibn 'Abbād de Sevilla propagó su linaje fecundando vigorosamente muchas mujeres. Una de ellas, la preferida, fue la hija de Muŷāhid, hermana uterina de Hasan. Se cuenta que al-Mu'tadid tuvo veinte hijos y veinte hijas. Al-Bayān al-mugrib, III, 207-8; trad. Maíllo Salgado, F., 175.

${ }^{67}$ Barceló, M., "Assaig", 46. Mu'izz al-Dawla fue quien negoció con Ahmad al-Muqtadir la entrega de Denia en 468 h. El relato de este episodio, en Turk, A., "El Reino de Zaragoza", 110-115. Por otra parte, un Muhammad b. 'Alī b. Muŷāhid consta como uno de los firmantes de un acuerdo entre el obispo Guislabert de Barcelona y 'Alī Iqbāl al-Dawla. A pesar de que existen pruebas de que se trata de una composición documental hecha en el XIII, hay que pensar que los nombres de los signatarios debían de constar en la cancillería episcopal y que no fueron una invención. Barceló, M. propuso la identificación de estos signatarios en "La qüestió dels documents d'un suposat acord entre 'Alī b. Muȳāhid de Dānya i el bisbe Guislabert de Barcelona”, Sobre Mayūrqa, Palma, 1984, 13-25, 19; Rubiera, M. J., La Taifa de Denia, 104. 
asociación en el gobierno, tal como hemos visto antes en el caso de las emisiones a nombre de Hasan. Por otra parte, tanto estas noticias como, sobre todo, la constante inscripción en las monedas, hasta 468 h., de los títulos sultánicos de 'Alī, en el reverso, y de Muhammad, en el anverso, revelan la estabilidad de esta asociación dinástica. Probablemente, la inclusión del título sultánico de Muhammad a partir de $442 \mathrm{~h}$. fue la manera de sancionar, no sólo la transmisión prevista - como se había hecho desde $437 \mathrm{~h}$. con el ism del sucesor-, sino, sobre todo, su participación en el mando del Estado.

Algunas series acuñadas en Denia incluyen, de todas maneras, otros nombres de identificación mucho más incierta. Se conocen dírhemes y dinares con el nombre 'Abd al-Malik inscrito siempre en el anverso. Las únicas fechas que aparecen en los dírhemes conocidos son $432 \mathrm{~h}$. y 433 h. ${ }^{68}$. No hay noticias de que 'Abd al-Malik fuera también hijo de 'Alī, ni de que fuera distinguido con ningún cargo en el mando del Estado. No hay tampoco ninguna base para pensar que se hubiera producido una interrupción transitoria del reconocimiento de Muhammad en la jerarquía de gobierno, considerando su larga vinculación a ésta (durante más de treinta años). Aunque no se puede demostrar, es plausible que este 'Abd al-Malik hubiera sido un personaje de la jerarquía palatina, pero de rango inferior. El hecho de que el nombre aparezca en el lugar donde se solía inscribir el nombre de los prefectos de la ceca en época califal podría hacer pensar que 'Abd al-Malik desempeñó este cargo, pero ello obligaría a aceptar una práctica ciertamente excepcional en las emisiones taifas, e inédita en las 'āmiríes.

La relación con puestos de mando más elevados resulta mucho más clara en el caso del apelativo al-fatà inscrito en las series de los años 467-468/1074-1076. Los fityān ocupaban los cargos principales en la administración palatina en época califal; constituían, tal como era transmitido en las representaciones ceremoniales, el envoltorio que contenía el corazón del Estado ${ }^{69}$. No parece probable que esta de-

68 El mismo año fueron acuñadas piezas con el laqab y el ism de Muhammad ibn 'Alī. Sáenz-Díez, J. I. y Vidal, J. M., "Dirhem inédito de Denia del año 443 en un tesorillo de Almería", Numisma, 186-191 (1984), 227-237, 231, n. 47.

69 Sobre el deslizamiento semántico del término para designar específicamente a los servidores con funciones políticas y administrativas, Meouak, M., Saqāliba, 97-99. Sobre la disposición ceremonial de los fityān, Barceló, M., "El califa patente", 152-154, y Lévi-Provençal, É., L'Espagne musulmane au Xème siècle. Institutions et vie sociale, París, 1932, 54-58.

Al-Qanțara (AQ) XXVII 2, julio-diciembre 2006, pp. 417-445 ISSN 0211-3589 
nominación hubiera correspondido a Muḥammad b. 'Alī, ya identificado en el mismo anverso con su propio laqab. Más bien habría que pensar en la inscripción honorífica de algún otro alto cargo de la administración, tal como se ha sugerido anteriormente en el caso de 'Abd al-Malik.

Este predominio de los nombres y de los títulos relacionados con el ejercicio del poder y de los oficios palatinos aparece aún más contundentemente en las series emitidas por los Banū Hūd a partir de 475/1082-1083. Mundir fue el primero que acuñó monedas en Denia tras la toma de la ciudad por al-Muqtadir, su padre. No se hizo constar reconocimiento califal alguno en ellas. Aparte del dogma de la singularidad de Dios en el anverso y la misión profética de Muhammad en el reverso, el resto de las leyendas centrales están ocupadas por nombres, cargos y títulos propios de la gestión del Estado. Así, en la serie emitida entre 475 y $482{ }^{70}$, consta el cargo de Mundir en la primera línea del reverso, su laqab en la segunda ('Imād al-Dawla), y el ism Mundir en la última. En el reverso, tras el dogma de la unicidad de Dios, aparece el nombre del sucesor previsto, Sulaymān ${ }^{71}$. Las monedas de Sulaymān, titulado Sayyid al-Dawla, siguieron la misma pauta, si bien no se acuñó el nombre del sucesor previsto ${ }^{72}$.

Por lo visto hasta ahora, las monedas acuñadas por los 'Āmiríes y por los Banū Hūd en Denia muestran el predominio creciente de las leyendas relacionadas con el ejercicio del poder estricto. Después de las producciones califales en las que las alusiones a la gestión del Estado aparecen discretamente con los nombres de los prefectos de la ceca, los mulūk instalados en Denia siguieron y consolidaron una pauta emisora en la que la estricta administración del poder político proveía los componentes principales de la legalidad, tal como era manifestada mediante las leyendas inscritas en las monedas. Sin duda, la experiencia decisiva en esta aparición mera y descarnada del Estado fue la creciente visibilidad de los gestores del poder desde Ibn Abī 'Āmir, preludio de una irrupción en la transmisión dinástica finalmente fracasada. Pero sí que tuvo éxito la posibilidad de construir una legalidad fuertemente impregnada de la organización del poder temporal.

70 Prieto, A., Los Reyes de Taifas, n. ${ }^{\circ} 299$.

71 Identificado por Caballero Infante, F., Estudio, 12.

72 Prieto, Los Reyes de Taifas, n. ${ }^{\text {s }} 300-303$. 
De todas maneras, no fue ésta una elaboración completamente nueva. El mantenimiento de las leyendas coránicas y de las alusiones califales, aun vacilantes y finalmente suprimidas por los Banū Hūd, muestran que la construcción de la legalidad de los mulük andalusíes habría sido inconcebible fuera de una tradición política que incluía, de manera tensa, los principios que canónicamente debían de regir la vida de la comunidad. Pero en cualquier caso la formalización de los nuevos poderes, encarnados en expertos palatinos, en antiguos supervisores de cecas, o en gobernadores más o menos integrados en el extinguido Estado califal, exigió sobre todo la confirmación inicial y posteriormente renovada de la autoridad por parte de los habitantes de la madina, de la sede de la dinastía. Antes se ha hecho referencia al compromiso de sumisión recibido por al-Muqtadir tras su entrada en Denia. Probablemente, Muŷāhid hubo de participar en un acuerdo de este tipo con sus habitantes más de sesenta años antes. En el mismo sentido podría interpretarse la confirmación de la autoridad de 'Alī b. Muŷāhid por parte de los cadíes de Denia después de la ruptura de la asociación con su hermano Hasan en el mando del Estado ${ }^{73}$.

Estas noticias permiten pensar que la legalidad con que se dotaron los mulūk andalusíes del V/XI admitía vacilaciones en el nombre del imām e, incluso, la elisión del imamato en las acuñaciones, pero el protocolo constitutivo de estos poderes preveía inevitablemente un pacto fundacional del nuevo sulțān con otras autoridades políticas ${ }^{74}$. Posiblemente, estos acuerdos iniciales, sancionados ceremonialmente con la bay' $a$ y sometidos a renovaciones periódicas, fijaban un amplio rango de sumisiones y compromisos. De esta manera se formalizaba la integración de algunos de los grupos representados por estas autoridades sometidas en la estructura del Estado. No haría falta observar la implicación de estas integraciones pactadas en los estatutos fiscales resultantes. Al fin y al cabo, se trataba de institucionalizar, por un lado, las relaciones que permitirían las acumulaciones de origen fiscal que habían de permitir la supervivencia de los grupos organizadores de Estados, y por otro, el propio ordenamiento de estos grupos ${ }^{75}$.

73 Al-Bayān al-mugrib, III, 157-8; trad. Maíllo Salgado, F., 137.

$74 \mathrm{Tal}$ relevancia del acuerdo fundacional del gobierno contrastaría con la consideración otorgada a la $b a y^{\prime} a$, por ejemplo, por al-Māwardī, para quien se trataba de un mero acto de reconocimiento, sin ningún sentido contractual; Lambton, A. K. S., State and Government, 90 . No interpreto de esta manera las noticias sobre estas ceremonias.

75 Barceló, M., "Al-Andalus, fer-se i desfer-se”, Musulmans i Catalunya, Barceló, 
Uno de los aspectos numismáticamente reconocibles de esta elaboración legal fue la fijación del orden dinástico y la asociación frecuente en el gobierno de miembros de la dinastía: hermanos en el caso de Hasan y de 'Alī b. Muŷāhid, y padre e hijo en los casos de 'Alī Iqbāl al-Dawla y de Muhammad Mu'izz al-Dawla, o de Mundir y Sulaymān de los Banū Hūd, más tarde. Estas asociaciones tuvieron que ver, sin duda, con las previsiones sucesorias, pero también puede pensarse que hubieran sancionado acuerdos que regularan el poder en el seno de las familias gobernantes. Esta manifestación numismática del sulțān desvelado se contemplaba con la inscripción eventual de nombres de personajes no identificados textualmente, pero que debieron constar en la jerarquía de servidores del Estado. El apelativo al-fatà, como se ha dicho antes, remite inconfundiblemente a este orden palatino, en concreto, a las tareas de gobierno y de administración.

F. Clément ha tratado de ponderar la relación entre la estabilidad de los diferentes Estados islámicos y la legitimidad otorgada por el estatuto - califato o gouvernorat, según su propia distinción - de estos Estados. Las conclusiones son claras y nada sorprendentes: «on ne constate pas de corrélation entre le statut du régime et son degré de stabilité politique». Y, por consiguiente, «le califat ne génère pas obligatoirement de l'ordre politique, ni les taifas du désordre» ${ }^{76}$. La cuestión de la «legitimidad», pues, no tiene un peso decisivo en la inteligibilidad de los procesos formativos de los Estados taifas, ni en los de su extinción ${ }^{77}$. Ciertamente, en la tradición política en cuyo seno tuvo lugar la formalización constitutiva de estos Estados andalusíes, los ensayos para resolver el imamato fueron insoslayables. De todas maneras, el problema principal y determinante del tamaño y de la perduración de tales Estados no fue el imamato, sino el mulk, la manera de organizar procedimientos duraderos de captura y de forzar sumisiones

M. (coord.), Barcelona, 1999, 11-38, 23; Retamero, F., La contínua il·lusió del moviment perpetu. La moneda dels reges, dels mulūk $i$ dels seniores (segles VI-XI), Universitat Autònoma de Barcelona, 2000, 174-178; Retamero, F. y Moll, B., "Moneda y madina. El caso de Madīna Manūrqa", La arqueología medieval en la arqueología, Granada, 2003, 205-239.

76 Clément, F., Pouvoir et legitimité, 301.

77 Contrariamente, Benaboud, M., "Religious knowledge and political power of the 'ulam $\bar{a}$ ' in al-Andalus during the period of the taifa status", Saber religioso y poder politico en el Islam, Madrid, 1994, 39-51.

Al-Qanțara (AQ) XXVII 2, julio-diciembre 2006, pp. 417-445 ISSN 0211-3589 
políticas estables. Así pues, serán principalmente las estimaciones sobre los ritmos y los volúmenes de producción de monedas y la distribución de los hallazgos, y no la estricta consideración de las fluctuantes formalizaciones de la relación entre jiläfa y mulk ensayadas por estos poderes, aquello que dará la medida más ajustada de su efímero fulgor. 